Vidya Wertta Volume 3 Nomor 1 Tahun 2020

p-ISSN 0852-7776-e-ISSN 2655-7282

https://ejournal.unhi.ac.id/index.php/vidyawertta

\title{
IMPLIKASI YURIDIS KONVERSI AGAMA TERHADAP KEDUDUKAN AHLI WARIS
}

\author{
I Gusti Ayu Ketut Artatik \\ I Gusti Ngurah Alit Saputra \\ Komang Indra Apsaridewi \\ Universitas Hindu Indonesia \\ Denpasar
}

\begin{abstract}
Abstrak
Konversi agama dari Hindu beralih ke agama lain merupakan masalah serius yang dihadapi oleh masyarakat Hindu di Bali saat ini. Seiring berkembangnya pola pikir masyarakat Hindu di Bali akibat globalisasi yang tidak diikuti oleh keseimbangan ekonomi keluarga dan kurangnya pemahaman tentang ajaran agama Hindu. Konversi agama banyak menyangkut masalah kejiwaan dan pengaruh lingkungan hidupnya. Jadi faktor penyebab konversi agama tersebut merupakan bentuk pembebasan diri dari tekanan bathin yang timbul dari dalam diri maupun dari lingkungan (eksternal). Implikasi konversi agama bagi seorang yang berpindah agama tentu saja tidak dapat lagi melaksanakan kewajiban leluhurnya sebagai seorang anak yang suputra (baik) terhadap leluhurnya, seperti melaksanakan upacara yadnya dan kewajiban - kewajiban sosial sebagai krama adat, dan juga seorang anak yang meninggalkan agama leluhurnya atau pindah agama dianggap juga sebagai sebab lenyapnya kedudukan mereka sebagai ahli waris. Adapun akibat hukum yang ditimbulkan dari konversi agama ini antara lain; akibat secara hukum Agama Hindu, akibat secara Hukum Adat Bali dan akibat secara hukum nasional, secara sistimatis memiliki keterikatan antara satu dengan yang lainnya.
\end{abstract}

Kata kunci: implikasi, yuridis, konversi agama

\begin{abstract}
Converting religion from Hinduism to other religions is a serious problem faced by the Hindu community in Bali today. Along with the development of the mindset of the Hindu community in Bali due to globalization which is not followed by a family economic balance and the lack of understanding of the teachings of Hinduism. Religious conversion involves a lot of psychological problems and environmental influences. So the factors that cause the conversion
\end{abstract}


of religion is a form of liberation from inner pressure arising from within and from the environment (external). The implications of religious conversion for a person who converts is certainly no longer able to carry out the obligations of his ancestors as a child who is suputra (good) to his ancestors, such as carrying out his yad ceremonies and social obligations as customary manners, and also a child who leaves his ancestral religion or moves religion is also considered as the cause of their disappearance as heirs. The legal consequences arising from the conversion of this religion include; Hindu legal consequences, Balinese customary law and national legal consequences, systematically have an attachment to one another.

Keywords: implications, juridical, religious conversion

\section{I . PENDAHULUAN}

Pesatnya perkembangan industri pariwisata di Bali membawa dampak heterogenitas kultur yang bercampur baur menjadi satu. Hal ini memberikan corak tersendiri bagi kultur masyarakat Bali yang berbasiskan spirit dan nilai - nilai Agama Hindu. Serta memiliki paradigma yang selama ini melekat pada masyarakat Bali, bahwa orang Bali adalah orang yang sangat terbuka, toleran dan ramah terhadap keberadaan suku, bangsa ataupun agama lain.Namun kontak atau interaksi dengan masyarakat pendatang tentu saja akan memberikan suatu pengaruh, baik secara disengaja maupun tidak disengaja bagi kedua belah pihak yang berinteraksi tersebut.Salah satu dampak dari interaksi masyarakat Bali dengan para pendatang adalah terjadinya konversi agama.

Melihat bagaimana konversi agama yang terjadi pada masyarakat Bali dari Hindu ke Kristen, tidak lepas dari pandangan orang bahwa masyarakat Bali selama ini terkenal sebagai benteng kebudayaan asli Nusantara yang terdesak oleh Islamisasi, para pemikir orientalis Barat pada era 1930 pun terkagum dengan kebudayaan masyarakat Bali yang cendrung melabeli Bali sebagai museum hidup. Perkembangan konversi agama ini pun juga telah menimbulkan kecemasan bagi masyarakat Bali, para peneliti pun mulai tertarik untuk fenomena ini dan mencari factor - factor internal dan eksternal yang menyebabkan terjadinya konversi agama ini. Hal ini dilakukan atas dasar spirit untuk memberikan solusi dan wacana yang mampu memberikan kritik destruktif bagi masyarakat Bali dalam hal menyikapi fenomena konversi agama, sebagai suatu konsekuensi logis dari adanya hubungan dengan masyarakat agama lain. ( Martha dan Sastra Wibawa, 2015:2)

Aryadharma $(2011 ; 8)$ berpendapat bahwa Konversi agama Hindu ke Kristen ini sebenarnya sudah terjadi dalam beberapa fase, dilakukan oleh para Missi Zending yang datang ke Bali sebagai wisatawan ataupun peneliti yang mengkaji kebudayaan Bali. Masyarakat Hindu di Bali pada umumnya dan khususnya di desa Dalung memiliki sifat yang terbuka dan toleran terhadap pendatang. Hal ini juga membuka peluang semakin berkembangnya jumlah penduduk pendatang yang non Hindu ke desa Dalung. Umat Nasrani baik yang menganut paham 
Katolik maupun Protestan yang ada di desa Dalung, di samping merupakan penduduk pendatang sebagian besar mereka adalah penduduk lokal desa Dalung yang mengalami konversi agama dari Hindu ke Katolik dan ke Protestan.

Mengingat sebagian besar dari mereka adalah masyarakat lokal yang mengalami konversi agama, maka dalam kesehariannya mereka menjalankan kehidupan bermasyarakat selayaknya tradisi masyarakat Hindu di Bali, seperti saling Ngejot apabila ada perayaan hari raya, saling nguopin atau metetulung ( saling membantu) apabila ada upacara keagamaan, saling mejenukan bila ada salah satu warga yang meninggal dunia, begitu juga ada yang saling kejuang atau menikah antara umat Hindu dengan umat Nasrani di desa Dalung.

Namun sebagai masyarakat yang terdiri atas dua komunitas, yaitu Nasrani dan Hindu sangat disadari kemungkinan terjadinya konflik sebab secara idiologi kedua keyakinan ini memang berbeda. Konversi agama dari Hindu beralih ke agama lain merupakan masalah serius yang dihadapi oleh masyarakat Hindu Bali saat ini. Seiring berkembangnya pola pikir masyarakat Hindu di Bali akibat globalisasi yang tidak diikuti oleh keseimbangan ekonomi keluarga dan kurangnya pemahaman tentang ajaran agama Hindu. Namun terlepas dari hal tersebut, masalah waris dalam masyarakat adat di Bali yang selalu memperhatikan kaedah - kaedah keagamaan, termasuk masalah beralih agama atau pindah agama bagi seseorang akan menjadi masalah baik pro dan kontra di dalam kedudukannya kelak bila terjadi pembagian harta warisan dalam keluarga.

Berbicara masalah warisan tidak terlepas dari hukum waris, nampaknya dari beragam sistem kekeluargaan yang dianut masyarakat Indonesia dengan tidak adanya hukum waris yang berlaku secara nasional, maka hukum waris yang berlaku bagi masyarakat Bali adalah Hukum Waris Adat Bali. Masyarakat Bali terikat oleh norma - norma hukum yang mengatur pergaulan hidup mereka, baik yang berupa hukum tertulis maupun hukum yang tidak tertulis. Hukum tertulis yang berlaku berasal dari negara dalam bentuk Peraturan Perundang - Undangan Republik Indonesia, sedangkan hukum yang tidak tertulis yang berlaku bersumber dari kebiasaan - kebiasaan masyarakat yang disebut Dresta. Jadi kondisi sosial budaya setiap suku bangsa mempunyai kekhasan masing - masing yang menyebabkan tidak mungkin semuanya dapat diatur secara nasional.

Menurut Windia ( 2006;115) mengatakan bahwa Hukum Adat Waris tidak lepas dari tiga kata kunci yang menjadi unsur pewarisan yaitu pewaris, harta warisan, dan ahli waris. Dalam aspek - aspek inilah akan dilihat asas - asas hukum adat waris yang berlaku bagi semua orang - orang Bali. Di dalam hukum waris Bali yang berhak mewaris adalah dari bapaknya atau dari garis keturunan si laki - laki, pewaris adalah orang yang akan memberikan warisannya kepada anaknya atau kepada ahli warisnya. Sedangkan warisan adalah sesuatu yang diwariskan baik berupa harta, nama baik dan lain - lain. Dalam hukum Adat Bali Warisan tidak hanya berupa harta benda saja tetapi juga berupa hak - hak kemasyarakatan. Dan Ahli Waris adalah orang yang nantinya akan menerima warisan. Pewarisan dalam Hukum Adat Bali tidak hanya berisi hak Ahli waris atas harta warisannya saja, lebih dari itu yang terpenting adalah kewajiban ahli waris terhadap pewaris. Jadi sebagai konsekuensi dari hak yang diterima, seorang ahli waris mempunyai kewajiban - kewajiban tertentu yaitu : 1) Memelihara 
pewaris ketika pewaris dalam keadaan tidak mampu, 2) Menguburkan jenazah pewaris dan atau menyelenggarakan Pengabenan ( upacara pembakaran jenazah) bagi pewaris dan menyemayamkan arwahnya di Sanggah atau Merajan (tempat persembahyangan keluarga), 3) Menyembah leluhur yang bersemayam di Sanggah atau Merajan, 4) Melaksanakan kewajiban - kewajiban ( ayahan) terhadap Banjar atau Desa Adat.

Ahli waris adalah mereka yang karena kedudukannya terhadap pewaris berhak menduduki tempat pewaris atas harta benda pusaka warisan itu. Pada prinsipnya semua ahli waris berhak mewaris, kecuali karena tingkah laku atau perbuatan hukum yang merugikan pewaris sehingga kedudukan ahli waris dapat dibatalkan berdasarkan hukum. Seperti yang termuat dalam hukum Perdata ( B.W ) Pasal 838 yang mengatur tentang orang - orang yang tidak patut menjadi ahli waris ( onwaardig) sebagai berikut: 1) Orang yang telah dihukum karena membunuh atau mencoba membunuh pewaris; 2) Orang yang dengan keputusan hakim pernah dipermasalahkan menfitnah si pewaris berupa fitnah dengan ancaman hukuman 5 tahun atau lebih berat. Dalam hal ini harus ada keputusan hakim yang menyatakan, bahwa yang bersangkutan bersalah karena menfitnah; 3) Orang yang dengan kekerasan atau perbuatan telah mencegah si pewaris untuk membuat atau mencabut surat wasiatnya; 4) Orang yang telah menggelapkan, merusak atau memalsukan surat wasiat si pewaris.

Lebih lanjut Gde Pudja ( 1997 ; 97 ) mengatakan bahwa seorang anak dikeluarkan sebagai ahli waris karena melanggar yang dapat mengancam kedudukan pewaris. Dengan kata lain sebagaimana disimpulkan dalam diskusi hukum Adat waris di Bali bahwa seorang anak laki yang berstatus ahli waris tidak akan menjadi ahli waris (mewaris), misalnya karena: a) durhaka (drowaka) terhadap leluhur ; b) durhaka (drowaka) terhadap orang tua. Disamping itu meninggalkan agama leluhur, dianggap juga sebagai sebab lenyapnya kedudukan mereka sebagai ahli waris. Kejadian inipun dapat dianggap sebagai kejadian durhaka terhadap leluhur karena sebagai akibat dari meninggalkan agama yang dianut leluhurnya, jelas mereka tidak akan dapat melakukan kewajibannya sebagai kewajiban seorang anak (putra) terhadap leluhurnya. Jadi seseorang yang pindah agama atau melakukan konversi agama di dalam hukum Hindu merupakan ahli waris yang tidak berhak mewaris.

Dalam kasus konversi agama yang terjadi di desa Dalung, bahwa ada satu keluarga yang telah beralih agama dari Hindu ke Kristen masih ada Sanggah di rumahnya, dan untuk mebanten di Sanggahnya ini dan saat melaksanakan Piodalan di Sanggahnya mereka menyuruh salah satu adik Perempuannnya yang telah kawin ke Tabanan untuk melaksanakan kewajibannya tersebut. Suatu hal yang biasanya menjadi masalah karena segala persiapan Piodalan tersebut diserakan kepada seorang tukang Banten (Srati Banten) untuk mengerjakannya. Dan karena keluarga tersebut telah berpindah keyakinan maka setiap Piodalan di Sanggahnya keluarga tersebut tidak ikut sembahyang di Sanggahnya, hanya menyiapkan segala keperluan upacara tersebut walaupun dengan memberikan ongkos kepada orang lain untuk mengerjakannya. Disamping itu keluarga yang melakukan konversi agama ini seharusnya masih mempunyai kewajiban sebagai Pengempon Sanggah Gede (Pura Dadia). Hal inilah yang menjadi masalah 
dikeluarga besarnya karena mereka tidak pernah lagi melaksanakan kewajibannya sebagai pengempon Pura tersebut. Fenomena konversi agama ini tentunya menjadi topik yang menarik untuk diteliti berkaitan dengan kedudukannya sebagai ahli waris dalam keluarga besar tersebut. Berdasarkan permasalahan ini, maka kami tertarik untuk menulis mengenai "Implikasi Yuridis Konversi Agama terhadap Kedudukan Ahli Waris di Desa Dalung”.

\section{II . PEMBAHASAN}

Implikasi Yuridis disebut juga dengan akibat hukum, dimana akibat hukum ini marupakan akibat suatu tindakan hukum, dimana yang dikehendaki dan yang di atur oleh hukum. Sudah menjadi suatu ketetapan bahwa setiap peristiwa pelaksanaan proses hukum pasti akan memiliki suatu akhir dari proses hukum tersebut, akhir dari segala prosedur hukum tersebut dinamakan dengan nama akibat hukum. Dimana akibat hukum akan memiliki suatu dampak bagi subyek maupun obyek hukum yang mengalami proses hukum.

Implikasi Yuridis menurut Martha dan Sastra Wibawa ( 2015: 62 ) mengatakan akibat hukum yang merupakan segala akibat konsekuensi yang terjadi dari segala perbuatan hukum yang dilakukan oleh subjek hukum terhadap objek hukum ataupun akibat - akibat lain yang disebabkan oleh kejadian kejadian tertentu oleh hukum yang bersangkutan sendiri telah ditentukan atau dianggap sebagai akibat hukum. Maka, akibat hukum konversi agama di Desa Dalung yang terkait dengan pewarisan merupakan sumber lahirnya hak dan kewajiban lebih lanjut bagi subyek - subyek hukum yang bersangkutan.

Konversi Agama adalah istilah yang pada umumnya diberikan untuk proses yang menjurus kepada penerimaan suatu sikap keagamaan, proses tersebut bisa terjadi secara berangsur - angsur atau bisa juga secara tiba - tiba. Konverse agama juga sering disebut dengan pindah agama atau pindah keyakinan.

Menurut Max Henrich (dalam D. Hendropuspito; 1983 : 78) mengatakan bahwa Konversi agama merupakan suatu tindakan dimana seseorang atau sekelompok orang masuk atau berpindah pada suatu sistem kepercayaan yang berlawanan dengan kepercayaan sebelumnya. Jadi konversi agama dikatakan sebagai suatu macam pertumbuhan atau perkembangan spiritual yang mengandung perubahan arah yang cukup berarti dalam sikap terhadap ajaran atau tindakan agama.

Konversi agama banyak menyangkut masalah kejiawaan dan pengaruh lingkungan tempat berada. Selain itu konversi agama yang dimaksudkan menurut beberapa pengertian dengan ciri - ciri sebagai berikut : 1) Adanya perubahan arah pandangan dan keyakinan seseorang terhadap agama dan kepercayaan yang dianutnya; 2) Perubahan yang terjadi dipengaruhi oleh kondisi kejiwaan sehingga perubahan dapat terjadi secara berproses atau secara mendadak; 3) Perubahan tersebut bukan hanya berlaku bagi perpindahan kepercayaan dari suatu agama keagama lain, tetapi juga termasuk perubahan pandangan terhadap agama yang dianutnya terjadi. 4) Selain faktor kejiwaan dan kondisi lingkungan maka perubahan itupun disebabkan faktor petunjuk dari yang Mahakuasa. Masalah 
konversi agama ini apabila dikaitkan dengan pewarisan kerapkali akan menimbulkan selisih paham. Dimana pewarisan merupakan salah satu hal yang cukup penting eksistensinya dalam kehidupan setiap orang karena pewarisan sering menimbulkan sengketa atau bahkan pertengkaran saudara atau keluarga yang menjadi ahli waris atas harta warisan yang ditinggalkan pewaris. Sengketa atau pertengkaran tersebut kerap terjadi apabila para ahli waris merasa ketidak adilan dalam pembagian harta warisan. Salah satu faktor yang bisa menimbulkan ketidak adilan dalam pembagian harta warisan adalah apabila dalam keluarga terdapat salah satu anggota keluarganya yang berbeda keyakinan atau mengalami konversi agama.

Berkenaan dengan kedudukan ahli waris pada orang yang pindah agama, perlu dipahami bahwa dalam hukum waris setidak - tidaknya ada tiga hal yang perlu diperhatikan yaitu : 1) adanya pewaris atau yang meninggalkan harta warisan; 2) adanya Ahli waris yang akan menerima harta warisan itu; 3) adanya Harta Warisan sebagai harta peninggalan pewaris kepada ahli warisnya. Gde Pudja ( 1997 : 85) dalam bukunya yang berjudul "Hukum Kewarisan Hindu yang Diresifir Kedalam Hukum Adat Bali dan Lombok" mengungkap tentang pewarisan yakni di dalamnya dibedakan antara pewaris dengan kewarisan. Dimana kewarisan menunjukkan pada pengertian yang mencakup hukum material dalam hal waris mewaris. Sedangkan pewarisan mencakup unsur pengertian hukum formil. Proses hukum adalah mengenai peralihan harta warisan dari pewaris atau yang meninggalkan harta warisan kepada ahli warisnya. Termasuk juga mengenai pewaris adalah ayah dan ibu atau saudara laki - laki tertua. Ahli waris adalah semua orang yang berhak menerima warisan. Harta warisan adalah harta benda yang dalam hukum Adat Bali disebut Druwe Tetamiyan dimana druwe tetamiyan adalah peninggalan hak milik dan orang yang telah meninggal sanak keluarga yang masih hidup. Masalah waris diakui oleh beberapa pihak sebagai salah satu bagian dari Hukum Adat di Bali yang paling sukar. Namun walaupun demikian bukan menjadi halangan untuk tidak membahasnya.

Lebih lanjut Gde Pudja mengatakan bahwa berdasarkan hukum waris B.W, tampilnya masalah ahli waris pada azasnya adalah karena meninggalnya pewaris sehingga dengan demikian terasa perlunya untuk menentukan siapa- siapa diantara orang - orang itu mempunyai kedudukan yang kuat dan sah menurut hukum untuk menggantikan kedudukan pewaris atas kedudukannya terhadap harta kekayaan yang ditinggalkan pewaris itu. Dari pengertian ini dapat dikatakan bahwa masalah pewarisan itu timbul hanya setelah pewaris meninggal.

Sedangkan yang dimaksud Ahli waris adalah setiap laki - laki dalam hubungan purusa selama tidak terputus haknya untuk menerima warisan, dan setiap sentana rajeg selama tidak terputus haknya untuk menerima warisan. Ahli waris dikatakan terputus haknya menerima warisan antara lain disebabkan: 1) anak laki - laki yang kawin nyeburin; 2) anak laki - laki yang tidak melaksanakan dharmaning anak seperti : Durhaka ( drowaka) terhadap leluhur, Durhaka ( drowaka) terhadap orang tua; 3) Sentana rajeg yang kawin keluar. Jadi dari uraian ini dapat dikatakan bahwa seseoarang yang mengalami pindah agama (konversi agama) akan menimbulkan akibat hukum terhadap kedudukannya 
sebagai ahli waris, baik dipandang dari hukum Agama, hukum Adat maupun Hukum Nasional.

\section{A - Implikasi Yuridis Konversi Agama Terhadap Hak Waris Menurut Hukum Hindu}

Dalam Hukum Waris Hindu disebutkan bahwa pewaris hakekatnya adalah bapak (Orang tua), sedangkan ahli waris adalah anak ( anak laki - laki), artinya warisan akan turun dari bapak kepada anak laki - lakinya. Hal ini tertuang dalam Kitab Manawa Dharmasastra Bab.IX, Pasal 156 dan pasal 158, yang bunyinya sebagai berikut:

Manawa Dharmasastra Bab IX. Pasal 156 :

"Samawarnasu ye jatah sarwe putras dwijanmanam uddahram jya yase datwa bhajeran nitare samam”.

Artinya :

Semua anak - anak dari orang dwijati yang lahir dari istri sederajat akan memperoleh bagian yang sama dari harta warisan setelah satu dengan yang lainnya memberikan tambahan kepada saudara tertuanya.

Manawa Dharmasastra Bab IX Pasal 158 :

" Putrandwadaca yanaha swa yambhuwo manuh tesam sad badha dayadah sad dayadhah bandhawah "

Artinya :

Sesungguhnya ada dua belas anak dari seseorang menurut Manu Swayambhu, enam diantaranya adalah mewaris dari keluarga, sedangkan yang lainnya tidak hanya sebagai keluarga.

Kitab Rg Veda : I. 37. 9, di sebutkan:

“Isanasah pitrvittsya rayah"

Artinya :

Anak laki - laki mewarisi milik ( harta ) leluhurnya

Kitab Rg Veda : I. 13. 4, disebutkan :

"Prajabhya pustim wibhajantha aastate”

Artinya :

Para orang tua memberikan bagian harta mereka pada anak laki - laki. 
Dari bunyi pasal - pasal di atas, anak yang termasuk ahli waris dalam Hukum Hindu adalah anak laki - laki baik itu anak kandung maupun anak angkat. Sedangkan anak yang bukan dari ahli waris tetapi masih sebagai keluarga adalah anak yang lahir dari perkawinan yang tidak sah ( tidak dinikahi), anak yang dapat dari membeli, anak yang menyerahkan diri( anak pungut) . Dalam Pasal 198 kitab Manawa Dharmasastra disebutkan ada enam anak yang sebagai ahli waris, yaitu enam anak yang akan mendapat warisan itu adalah :

1. Anak yang lahir dari perkawinan pertama

2. Anak yang lahir dari istri kedua ( perkawinan yang mendapatkan persetujuan dari keluarga)

3. Anak pemberian saudara, anggota keluarga

4. Anak yang diminta dari orang lain diangkat sebagai anak

5. Anak yang diperoleh dari istri yang atas persetujuan suaminya bercampur dengan iparnya

6. Anak buangan yang dipungut dan diakui sebagai anak

Sedangkan enam anak yang tidak mendapatkan warisan adalah :

1. Anak yang tidak diketahui siapa bapaknya, diperoleh ibunya ketika masih gadis

2. Anak campuran orang ( dihamili oleh banyak laki - laki)

3. Anak seorang istri yang sudah diceraikan dan kawin lagi dengan laki - laki lain

4. Anak yang diperoleh karena pemberian

5. Anak orang lain yang diminta diakui sebagai anak

6. Anak hamba yang berasal dari keturunan rendah yang diakui sebagai anak.

Disamping anak laki - laki, anak Perempuan juga berhak mendapat warisan, seperti yang tertuang dalam kitab Rg Veda dan kitab Manawa Dharmasastra, sebagai berikut:

" Amajur iva patrohsaca sati samanada a asadasas tvaam iye bhagam kridhipraketam upa masya bhara daddhi bhagam tanvo yane mamahah" ( Rg Veda: II.17.7 )

Artinya :

Seorang anak yang selalu tinggal dengan orang tuanya, seperti seorang wanita yang tinggal menjadi orang tua dirumah, meminta uang kepada orang tuanya. Semoga orang tuanya memikirkan itu. Perhitungkan dan berikan bagiannya kepadanya untuk perawatan diri dan menjamu para tamu.

"Yataiwama thata putra patrena duhita soma tasyamatmani tishantayam kathamanyo dhanam haret " ( MD. IX. 130)

Artinya : 
Seorang anak sama dengan dirinya sebagaimana anak perempuan sama dengan anak laki - laki, bagaimana mungkin orang lain memperoleh harta warisan sedangkan anak perempuan yang ditunjuk, seorang yang ditunjuk yang sama dengan dirinya masih hidup.

"Matusu yautakam yat syakumara bhaga ewash dauhita ewa ca hareda putrasyakilam dhanam" ( MD. IX. 131 )

Artinya :

Tetapiapapun juga harta sendiri milik ibu, harta itu adalah satu - satunya merupakan bagian anak perempuan dan anak wanita yang diangkat statusnya menjadi anak laki - laki menerima seluruh warisan orang tuanya yang tidak berputra lagi.

Dari bunyi pasal di atas dapat diketahui bahwa seorang anak perempuan berhak mendapatkan warisan orang tuanya baik ibu maupun bapaknya, terlebih lagi jika perempuan itu diangkat statusnya menjadi laki - laki ( Putrika). Seorang anak disampin berhak atas warisan orang tuanya, mereka juga memiliki kewajiban yang harus dipikul sebagai seorang anak. Seperti yang tertuang dalam kitab Nitisastra Bab II. 3 - 4, dan juga Kitab Manawa Dharmasastra Bab. IV Pasal 180, yang masing - masing bunyinya sebagai berikut :

"Yasya putro vasibhuto bharyachandanugani vibhave yasca santutas tasys svarga ihaiva hi” ( Nitisastra: II.3 )

Artinya :

Kalau seorang anak bhakti kepada orang tuanya, sang istri penurut, merasa puas terhadap harta benda yang dimiliki, sebenarnya kesenangan Surga dinikmati oleh orang - orang tersebut di dunia.

"Te putra ye pitur- bhaktah sa pita pasokah tam mitram yatra visvasah sa bhaarya yatra nirvrtih" ( Nitisastra: II. 4 )

Artinya :

Yang disebut putra adalah mereka yang bhakti terhadap bapak, yang disebut bapak adalah ia yang menanggung, memelihara anak - anaknya. Yang disebut teman adalah ia yang percaya dan dapat dipercaya, dan seorang istri adalah ia yang selalu memberikan kebahagiaan.

“ Matapitribham jambhirbhratra putrena bharyaya, duhitra dasa wargena wiwadam na samacaret” ( MD: IV. 10 )

Artinya :

Janganlah ia sampai berkelahi dengan ayah bundanya sendiri, dengan keluarga - keluarga perempuannya, dengan kakak- kakaknya, dengan anak istrinya, dengan putrinya dan dengan pelayan - pelayannya sekaligus. 
Jadi tanggung jawab yang harus diemban oleh seorang anak laki - laki atau seorang wanita yang berstatus laki - laki ( Putrika), sebagaimana yang di sebutkan di atas adalah berbakti kepada leluhur dengan cara melakukan upacara upacara ritual, menghormati leluhur, orang tua, saudara dan juga para gurunya dengan senantiasa menyenangkan hati mereka. Menghindari perselisihan, perkelahian dengan orang tua ataupun dengan keluarga lainnya.

Dari beberapa kutipan pasal di atas dikatakan bahwa setiap ahli waris sebenarnya mendapatkan hak waris dari pewaris ( orang tuanya), namun adakalanya seseorang akan kehilangan hak warisnya disebabkan karena perbuatannya yang bertentangan dengan norma - norma hukum yang berlaku baik itu hukum agamanya ataupun hukum adatnya. Hilangnya hak mewaris terhadap harta warisan disebabkan oleh beberapa hal seperti :

1. Membunuh atau berusaha menghilangkan nyawa pewaris atau anggota keluarga atau pewaris.

2. Melakukan penganiayaan atau berbuat merugikan kehidupan si pewaris.

3. Berbuat tidak baik ataupun menjatuhkan nama baik pewaris atau kerabat pewaris karena perbuatan tercela.

4. Meninggalkan agamanya atau berpindah agama ataupun kepercayaan. (Gegel,2006:148)

Lebih lanjut dalam hukum Hindu dikatakan seorang ahli waris akan kehilangan hak warisnya atau tidak berhak mewaris seperti yang diatur dalam Pasal 201, 214 Bab IX Kitab Manawa Dharmasastra adalah jika:

1. Ahli Waris menolak untuk mewaris

2. Ahli Waris durhaka terhadap leluhurnya ( Pewaris )

3. Ahli Waris dianggkat anak oleh orang lain

4. Ahli waris menikah dengan Putrika (anak wanita yang berstatus Purusa)

Jadi dalam masyarakat Hindu di Bali, seorang anak dapat pula kehilangan hak warisnya apabila anak tersebut mempunyai tingkah laku dan perbuatan yang dapat mengancam kehidupan pewaris bahkan sampai membunuhnya. Apalagi sampai meninggalkan agama leluhurnya atau pindah agama. Dimana seseorang yang telah pindah agama tidak dapat melaksanakan kewajiban terhadap leluhurnya seperti menyembah dan melaksanakan upacara yadnya menurut agama leluhurnya.

\section{B. Implikasi Yuridis Konversi Agama Terhadap Hak Waris Menurut Hukum Adat Bali}

Ahli waris adalah orang yang menerima warisan. Menurut Soerjono Soekanto $(2002 ; 261)$ mengatakan tentang ahli waris dalam hukum adat dikenal adanya penggolongan ahli waris berdasarkan garis pokok keutamaan dan garis pokok pengganti. Garis pokok keutamaan adalah garis hukum yang menentukan urutan - urutan keutamaan diantara golongan - golongan keluarga pewaris dengan pengertian golongan yang satu lebih diutamakan dari golongan yang lain. Garis pokok pengganti adalah garis hukum yang bertujuan untuk menentukan 
siapa - siapa diantara kelompok keutamaan tertentu tampil sebagai ahli waris. Dalam ahli waris yang menentukan berdasarkan garis pokok keutamaan dan garis pengganti ini harus diperhatikan sistem kekeluargaan yang berlaku. Dengan garis - garis pokok keutamaan tadi, maka orang - orang yang memiliki hubungan darah dibagi dalam golongan - golongan, yaitu :

1. Kelompok keutamaan pertama adalah keturunan pewaris;

2. Kelompok keutamaan kedua adalah orang tua waris;

3. Kelompok keutamaan ketiga adalah saudara - saudara pewaris dan keturunannya;

4. Kelompok keutamaan keempat adalah kakek dan nenek pewaris dan seterusnya.

Gde Panetja ( 1989 ; 164) menyatakan masyarakat Hukum Adat Bali yang berdasarkan pada sistem kekeluargaan kepurusa, adalah orang - orang yang dapat diperhitungkan sebagai ahli waris dalam garis pokok keutamaan dan garis pokok pengganti adalah para laki - laki dalam keluarga yang besangkutan, sepanjang tidak terputus haknya sebagai ahli waris. Kelompok orang - orang yang termasuk dalam garis keutamaan, pertama sebagai ahli waris adalah keturunan ahli waris kencang kebawah, adaah anak kandung laki - laki atau anak perempuan yang ditingkatkan statusnya sebagai penerus keturunan ( Sentana Rajeg ) dan anak angkat ( Sentana Peperasan). Sentana Rajeg dan Sentana Peperasan mempunyai hak yang sama dengan anak kandung laki - laki terhadap harta warisan. Anak perempuan dan janda bukanlah ahli waris, tetapi apabila anak perempuan itu tidak kawin ( Deha tua), maka ia berhak atas harta orang tuanya sebagai nafkah hidupnya ( pengupa jiwa).

Apabila ahli waris dari golongan keutamaan pertama tidak ada, maka yang berhak terhadap harta warisan adalah golongan ahli waris keutamaan kedua, yaitu orang tua pewaris jika masih ada. Setelah itu barulah diperhitungkan saudara saudara pewaris sebagai kelompok keutamaan ketiga dan keturunannya sebagai ahli waris pengganti.

Pewarisan dalam hukum Adat Bali bukan semata - mata berisi hak ahli waris terhadap harta warisan saja, namun lebih dari itu yang terpenting adalah kewajiban ahli waris terhadap pewaris. Kewajiban ahli waris ini merupakan konskuensi dari hak yang diterimanya. Seorang ahli waris memiliki kewajiban kewajiban tertentu yaitu :

1. Memelihara pewaris dalam keadaan tidak mampu;

2. Menguburkan jenasah pewaris atau menyelenggarakan pengabenan ( upacara pembakaran jenazah) bagi pewaris untuk menyemayamkan arwahnya di Sanggah / Merajan ( tempat persembahyangan keluarga);

3. Menyembah arwah leluhur yang bersemayam di Sanggah / Merajan

4. Melaksanakan kewajiban - kewajiban ( ayahan ) terhadap Banjar / Desa

Jadi kelalaian terhadap kewajiban - kewajiban diatas dapat dijadikan alasan untuk putusnya hak seseorang sebagai ahli waris. Atau dapat dikatakan bahwa 
ahli waris terputus haknya menerima harta warisan karena beberapa alasan yaitu sebagai berikut : a) Anak laki - laki kawin nyeburin; b) Anak laki - laki tidak melaksanakan Dharmaning anak ( seperti: durhaka terhadap leluhur, dhurhaka terhadap orang tua); c) Sentana rajeg yang kawin keluar. Pada dasarnya dalam hukum Adat Bali berkenaan dengan pewarisan, bukan semata - mata berisi hak saja tetapi ada juga kewajiban - kewajiban yang harus dipenuhi dalam upaya mendapat warisan dan apabila salah satu kewajiban diabaikan maka dapat menimbulkan terputusnya hak untuk menerima warisan.

Dalam kehidupan bermasyarakat adat di Bali diatur dalam Awig-Awig yang merupakan peraturan - peraturan desa yang lahir dari keputusan - keputusan bersama yang wajib dituruti oleh semua krama desa. Berkenaan dengan waris, ahli waris, pewaris dan hilangnya hak waris krama desa Adat Padang Luwih di Dalung, tertuang dalam Ekalikita ( Awig - Awig ) Desa Adat Padang Luwih ( 2014; 49-51), sebagai berikut:

\section{Pawos 51 ( Pasal 51):}

(1) Warisan inggih punika tetamian artha brana saha ayah-ayahan ngupadi kasukertan sekala niskala keluhurania ring tuturanya

Artinya :

Warisan adalah peninggalan baik berupa harta benda maupun kewajiban kewajiban yang harus dilakukan untuk menjaga keharmonisan lahir bathin dari leluhurnya terhadap ahli warisnya.

(2) Kang sinanggeh Warisan luwire:

(Ha) Due tengah; mekadi tegal, ayahan desa, khayangan pusaka siwa pakarana lan

Sapanunggalnya

(Na) Pemerajan / Sanggah

(Ca) Pangunakaya, tadtadan / jiwa dana, hutang piutang

Artinya :

Yang disebut sebagai harta warisan diantaranya :

(a) Harta milik bersama, sepeti ladang, kewajiban desa Pekraman / Adat

(b) Pura Keluarga ( Merajan / Sanggah )

(c) Penghasilan Jerih Payah, harta benda bekal perkawinan dan hutang piutang.

\section{Pawos 52 ( Pasal 52)}

Swadarmaning ahli waris, inggih punika;

(Ha) Nerima saha ngusahayang tetamian pahan saking keluhurania, mekadi 
Ngerempon Sanggah, pura saha pengupakarania miwah nyeledihin ayah-ayahan pewaris yadnya

(Na) Ngabenan pewaris saha ngelanturang upacara - upacara pitra

(Ca) Naurin hutang - hutang pewaris manut pangalogika.

Artinya : Kewajiban seorang ahli waris, adalah sebagai berikut:

(a) Menerima dan menguasai bagian warisan dari pewarisnya, seperti memelihara Sanggah, Pura serta segala upacaranya dan juga meneruskan kewajiban pewaris.

(b) Melakukan upacara Pitra Yadnya ( Ngaben) untuk pewaris serta melanjutkan upacara - upacara Pitra Yadnya.

(c) Membayar hutang - hutang pewaris sesuai ketentuan

\section{Pawos 53 ( Pasal 53)}

Pengepahan waris, manut sekadi ring sor ; buntas

(Ha) Risampun kelaksanayang Pitra Yadnya lan hutang - hutang pewaris

(Na) Para ahli waris polih pahan sangkaning pangunakaya, saha tegal / karang ayahan desa koemong oleh waris, kang sinanggeh krama ngarep.

(Ca)Sinalih tunggil ahli waris kengin tan polih pahan prade:

1) Nilar kawitan lan sesananing agama

2) Alpaka guru rupaka

3) Sentana rajeg, kesah mawiwahe utawi pratisentana nyeburin soang-soang kebawos ninggal kadaton

(Ra) Boye ahli waris, kengin muponin hasil manut dudonan, luire:

1) Sentana luh, selami during kesah mewiwahan

2) Balu luh wiadin muani nyeburin (soang - soang boye sentana)

3) Mulih deha utawi truna, riantukan ring pawiwahan pecak sampun kabawos nunggal kadaton.

Artinya : Pembagian waris sepatutnya seperti di bawah:

(a) Sesudah pelaksanaan ngaben dan pelunasan hutang - hutang leluhur selesai dibayar.

(b) Para ahli waris dapat bagian atas harta guna kaya atau harta kekayaan leluhur, dan karang / tegal ayahan desa keamong oleh ahli waris, yang disebut Krama Ngarep.

(c) Salah satu penyebab ahli waris tidak mendapat waris, karena: 
1) Meninggalkan hak kepatutan ( hak waris) dan meninggalkan kewajiban beragama atau pindah agama ( dari agama Hindu ke agama lain)

2) Durhaka terhadap leluhur

3) Ahli waris perempuan, kawin keluar atau ahli waris laki - laki kawin nyeburin atau nyentana, masing - masing disebut ninggal kedaton atau meninggalkan hak warisnya.

(d) Bukan ahli waris, tetapi bisa menikmati hasil dari harta warisan tersebut, seperti:

1) Seorang perempuan yang belum atau tidak menikah

2) Janda atau duda yang kawin nyeburin

3) Kembali kerumah asal karena cerai.

Dari kutipan pasal - pasal ( Pawos) yang ada dalam Awig - Awig tersebut di atas, sangat jelas diatur bahwa orang yang berpindah agama atau tidak lagi menjalankan kewajibannya beragama Hindu, maka hak dan kewajiban sebagai krama desa adat akan putus dalam artian tidak lagi diakui sebagai krama desa Adat. Namun masalah harta warisan pribadi atau harta warisan dari orang tuanya tergantung dari kesepakan keluarganya untuk memberikan kepada seseorang yang melakukan konversi agama.

Dapat disimpulkan bahwa ahli waris yang berpindah agama, dari pewaris tidak berhak mewariskan harta warisannya karena tidak melaksanakan kewajiban atau drowaka ( durhaka kepada leluhur karena meninggalkan agama leluhur). Kewajiban ahli waris dalam masyarakat hukum adat Bali yang terkait erat dengan kewajiban dalam bidang keagamaan ( Agama Hindu). Dimana kewajiban seorang ahli waris adalah melakukan sembah atau menyembah (penghormatan) kepada leluhur atau pewaris ( orang tua) pada saat upacara pengabenan (Pitra Yadnya). Serta secara berkelanjutan untuk melaksanakan upacara yadnya ditempat persembahyangan seperti Sanggah atau Merajan, juga selaku masyarakat adat berkewajiban menyungsung pura Khayangan Tiga. Berkenaan dengan harta kekayaan, ahli waris yang pindah agama hanya dapat diberikan pemberian pemberian sebatas harta gunakaya atau harta gonogini orang tuanya.

\section{Implikasi Yuridis Konversi Agama Terhadap Hak Waris Menurut Hukum Nasional}

Hukum waris adalah hukum yang mengatur tentang peralihan harta kekayaan yang ditinggalkan seseorang yang meninggal serta akibatnya bagi para ahli warisnya. Pada asasnya hanya hak - hak dan kewajiban - kewajiban yang dapat diwariskan. Menurut Effendi Perangin ( 2014; 1 ) menegaskan dalam surat edaran Mahkamah Agung kepada para Ketua /Hakim Pengadilan Tinggi dan para Ketua/Hakim Pengadilan Negeri tanggal 20 Agustus 1975 No.M.A/ Penb/007/75 tentang petunjuk - petunjuk pelaksanaan UU No.1 Th 1974 dan PP No.9 Tahun 1975. Tentu saja ketentuan - ketentuan hukum waris dalam KUHPer hanya berlaku bagi mereka yang tunduk atau menundukkan diri kepada KUHPer itu. Mereka yang tunduk kepada KUHPer, khususnya mengenai hukum waris ialah 
warga negara Indonesia keturunan Tionghoa dan Eropa. Sedangkan sebagaian besar rakyat Indonesia tunduk kepada hukum Adat. Di berbagai daerah ketentuan - ketentuan mengenai pewarisan yang diatur dalam hukum Islam telah meresap kedalam hukum Adat.

Berkaitan dengan hal tersebut Gde Pudja ( 1977 ; 9) mengatakan bahwa walaupun pasal 29 UUD 1945 itu sangat singkat, terdiri dari 2 ayat saja, namun sangat penting sekali artinya dalam pentrapan Pancasila dalam pembentukan masyarakat Indonesia yang utuh. Sebagai satu landasan hukum, pasal inipun akan mempunyai pengaruh yang besar dalam mengakomodasikan aspek - aspek hukum yang bersumber pada ajaran agama. Dengan hukum agama yang dimaksud tidak saja hukum agama Islam saja, tetapi juga menyangkut hukum Hindu bagi masyarakat yang beragama Hindu. Jadi berdasarkan pasal ini negara menjamin bahwa hukum Agama yang telah meresap ke dalam hukum Adat dapat dijalankan menurut kepercayaannya itu.

Dalam kasus pewarisan yang berkaitan dengan konversi agama yang terjadi di Banjar Kwanji Dalung, telah diawali dengan sangkepan / rapat keluarga besar kemudian dilanjutkan dengan sangkepan/ rapat desa Adat dan tindakan mediasi dari Perbekel serta aparat Desa Dalung. Tindakan sangkepan dan mediasi dalam menangani sebuah kasus merupakan bentuk dari penerapan prinsip hukum progresif. Dimana jika terjadi permasalahan akan diselesaikan terlebih dahulu dari tingkat paling bawah dengan suasana kekeluargaan, mendengarkan aspirasi mereka yang mengalami kasus hukum secara bersama - sama. Hukum progresif merupakan bentuk penghormatan terhadap hak - hak warga masyarakat untuk diadili tidak sebatas dengan aturan tertulis hitam di atas putih saja dalam peraturan desa ( di Bali di sebut Awig - Awig dan Pararem), melainkan dengan menggali keadilan yang hakiki sebelum dijatuhkan akibat hukum terhadap suatu perbuatan.

Dasar filosofi dari pemikiran hukum progesif adalah suatu institusi yang bertujuan mengantarkan manusia kepada kehidupan yang adil, sejahtera dan membuat manusia bahagia. Pemikiran hukum progresif berangkat dari asumsi dasar bahwa hukum adalah untuk manusia bukan sebaliknya. Berdasarkan hal itu, maka kelahiran hukum bukan untuk dirinya sendiri, melainkan untuk sesuatu yang lebih luas, yaitu; untuk harga diri manusia, kebahagiaan, kesejahtraan dan kemuliaan manusia. Itulah sebabnya ketika terjadi permasalahan didalam hukum, maka hukumlah yang harus ditinjau dan diperbaiki, bukan manusia yang dipaksa - paksa untuk dimasukan kedalam skema hukum. ( Martha dan Sastra Wibawa : $2015 ; 115)$

Jadi hukum progresif dalam hal akibat hukum konversi agama dipandang selain adanya suatu kepastian hukum, sangat penting kiranya menggali kearifan lokal dalam suatu wilayah yang nantinya digunakan sebagai dasar dan aturan yang tertuang dalam suatu peraturan, baik yang berasal dari norma agama yang diyakininya dan berorientasi untuk menjaga kerukunan kehidupan bermasyarakat.

\section{KESIMPULAN}


Berdasarkan pembahasan permasalah yang diuraikan di atas, dapat diberikan simpulan sebagai berikut :

Implikasi Yuridis Konversi Agama Terhadap Hak Waris Menurut Hukum Hindu, adalah seorang anak dapat pula kehilangan hak warisnya apabila anak tersebut mempunyai tingkah laku dan perbuatan yang dapat mengancam kehidupan pewaris bahkan sampai membunuhnya. Apalagi sampai meninggalkan agama leluhurnya atau pindah agama. Dimana seseorang yang telah pindah agama tidak dapat melaksanakan kewajiban terhadap leluhurnya seperti menyembah dan melaksanakan upacara yadnya menurut agama leluhurnya.

Implikasi Yuridis Konversi Agama Terhadap Hak Waris Menurut Hukum Adat Bali adalah seorang yang berpindah agama atau tidak lagi menjalankan kewajibannya beragama Hindu, maka hak dan kewajiban sebagai krama desa adat akan putus dalam artian tidak lagi diakui sebagai krama desa Adat. Namun masalah harta warisan pribadi atau harta warisan dari orang tuanya tergantung dari kesepakan keluarganya untuk memberikan kepada seseorang yang melakukan konversi agama.

Implikasi Yuridis Konversi Agama Terhadap Hak Waris Menurut Hukum Nasional adalah dalam kasus pewarisan yang berkaitan dengan konversi agama yang terjadi di Banjar Kwanji Dalung, telah diawali dengan sangkepan / rapat keluarga besar kemudian dilanjutkan dengan sangkepan/ rapat desa Adat dan tindakan mediasi dari Perbekel serta aparat Desa Dalung. Tindakan sangkepan dan mediasi dalam menangani sebuah kasus merupakan bentuk dari penerapan prinsip hukum progresif. Dimana selain adanya suatu kepastian hukum, sangat penting kiranya menggali kearifan lokal dalam suatu wilayah yang nantinya digunakan sebagai dasar dan aturan yang tertuang dalam suatu peraturan, baik yang berasal dari norma agama yang diyakininya dan berorientasi untuk menjaga kerukunan kehidupan bermasyarakat.

\section{DAFTAR PUSTAKA}

Arinanto, Satya,2008, Hak Asasi Manusia dalam transisi Politik, Jakarta: Pusat study Hukum Tata Negara Fakultas Hukum Universitas Indonesia

Aryadharma, Surphi, 2011, Membedah Kasus Konversi Agama di Bali, Denpasar; Paramita

Bungin, Burhan. 2001. Metodologi Penelitian Sosial Format-Format Kualitatif dan Kuantitatif. Surabaya: Airlangga Universty Press.

Atmaja, Nengah Bawa, 2005, Bali Pada Era Globalisasi: Pulau Seribu Tidak Seindah Penampilannya, Singaraja; Paramita

Departemen Pendidikan Nasional. 2005. Kamus Besar Bahasa Indonesia. Jakarta: Balai Pustaka.

D. Hendropuspito, 1983, Sosiologi Agama, Yogyakarta; Kanisius 
Darma Putra, I Nyoman (ed), 2004; Bali Menuju Jagadhita Aneka Perspektif. Denpasar; Pustaka Bali

Dharmayuda, I Made Suasthawa. 2001; Desa Adat Kesatuan Masyarakat Hukum Adat di Propinsi Bali; Denpasar ; PT Upada Sastra

Effendi Perangin,2014, Hukum Waris, Jakarta, PT Raja Grafindo Persada

Gelgel. I Putu. 2006. Hukum Hindu Ruang Lingkup Dan Sumber - Sumbernya, Denpasar; Pustaka Bali

Griya . I Wayan, 2000; Transformasi Kebudayaan Bali Memasuki Abad XXI. Denpasar; Dinas Kebudayaan Provinsi Bali

Goode, William J. 2007. Sosiologi Keluarga. Diterjemahkan oleh: Lailahanoum. Jakarta: PT Bumi Aksara.

Gulo, W. 2002. Metodologi Penelitian. Jakarta: Grasindo.

Imam Tholkhah. 2001. Mewaspadai dan Mencegah Konflik Antar Umat Beragama; Jakarta; Departemen Agama RI

Koentjaraningrat. 2002. Manusia dan kebudayaan di Indonesia, Jakarta; Djembatan

Kajeng, I N., dkk. 1999. Sarasamuccaya. Surabaya: Paramita

Koentjaraningrat. 1993. Ritus Peralihan di Indonesia. Jakarta: Balai Pustaka.

Martha. I wayan dan I Putu Sastra Wibawa. 2015. Implikasi Yuridis Rekonversi

Agama. Denpasar: Universitas Hindu Indonesia

Makasiman, M. 2002. Saling Asih, Saling Asuh, Saling Asah: Suatu Renungan

Bebas. Jakarta.

Moleong, Lexy J. 2010. Metodologi Penelitian Kualitatif. Bandung: Remaja

Rosdakarya..

Parisadha Hindu Dharma Indonesia. 2006. Himpunan Kepustusan Seminar Kesatuan

Tafsir terhadap Aspek-Aspek Agama Hindu I-IX: Pemerintah Provinsi Bali.

Panetje,Gde. 1989, Desa Adat Dalam Perspektif Sejarah Dinamika Kebudayaan, Denpasar; Universitas Udayana

Prabhu, Dharmayasa. 2013. Bhagawad Gita. Denpasar: Yayasan Dharma Sthapanam 
Puja,G. 1997. Hukum Kewarisan Hindu Yang Diresepir Kedalam Hukum Adat di Bali dan Lombok. Jakarta; CV Junesco

Puja, G., dan Tjokorda Rai Sudharta. 2004. Manawa Dharmacastra (Manu Smerti)

Kompedium Hukum Hindu. Surabaya: Paramita.

Ritzer, George dan Douglas J. Goodman. 2005. Teori Sosiologi Modern.

Sutrisno, M., dan Hendar Putranto. 2005. Teori-Teori Kebudayaan. Yogyakarta:

Kanisius.

Soerjono Soekanto, 2002, Hukum Adat Indonesia, Jakarta; PT Raja Grafindo Persada

Tantra, Dewa Komang. 2015. Solipsisme Bali : Antara Persatuan dan Perseteruan.

Denpasar: Wisnu Press.

Triguna,IB. G.Yudha.2008; Kebudayaan dan Modal Budaya Bali Dalam Teropong

Lokal, Nasional, Global. Denpasar; Widya Dharma

Wiana, I Ketut. 2007. Tri Hita Karana Menurut Konsep Hindu. Surabaya: Paramita. 